\title{
Copula in Wildfire Analysis: A Systematic Literature Review
}

\author{
Mohamad Khoirun Najib ${ }^{1 *}$, Sri Nurdiati ${ }^{1}$ and Ardhasena Sopaheluwakan ${ }^{2}$ \\ ${ }^{1}$ Department of Mathematics, IPB University, Bogor 16680, Indonesia \\ ${ }^{2}$ Agency for Meteorology, Climatology, and Geophysics, Jakarta 10720, Indonesia \\ Email: \{mkhoirun_najib, nurdiati\}@apps.ipb.ac.id, ardhasena@bmkg.go.id
}

\begin{abstract}
Copula model is a method that can be implemented in various study fields, including analyzing wildfires. The copula distribution function gives a simple way to define joint distribution between two or more random variables. This study aims to review the application of copula in the analysis of wildfires using a Systematic Literature Review (SLR) and provide insight into research opportunities related to the application in Indonesia. The results show there are very few articles using the copula model in the analysis of wildfires. However, the increasing number of article citations each year shows the importance of such article research and has contributed to wildfire analysis development. In that article, $50 \%$ of studies applied the copula model to direct wildfire analysis (using fire data) in Canada, Portugal, and the US. Meanwhile, the other $50 \%$ use the copula model for indirect wildfire analysis (not using fire data) in Canada and the European region. The outcome of the presented review will provide the latest research positions and future research opportunities on the application of copula in the analysis of wildfires in Indonesia.
\end{abstract}

Keywords: copula; wildfire; systematic literature review.

\begin{abstract}
Abstrak
Model copula merupakan metode yang dapat diimplementasikan pada berbagai bidang penelitian, salah satunya pada analisis kebakaran butan. Fungsi sebaran copula memberikan cara yang mudah untuk mendefinisikan sebaran peluang bersama antara dua peubah acak atau lebih. Tujuan penelitian ini mengulas penerapan model copula tersebut pada analisis kebakaran butan dalam studi literatur menggunakan Systematic Literature Review (SLR) serta memberikan peluang riset ke depan terkait implementasinya pada analisis kebakaran butan di Indonesia. Hasil penelitian menumjukean babwa model copula pada analisis kebakaran hutan masib sangat sedikit. Namun, peningkatan jumlah sitasi artikel tiap tabun menunjukkan pentingnya penelitian tersebut dan memiliki kontribusi pada perkembangan analisis kebakaran butan. Pada artikel tersebut, sebanyak, 50\% penelitian menerapkan model copula pada analisis kebakaran secara langsung (menggunakan data kebakaran) di Kanada, Portugal, dan Amerika. Sementara, sebanyak 50\% lainny menerapkan model copula pada analisis kebakaran secara tak langsung (tidak menggunakan data kebakaran), yaitu di Kanada dan kawasan Eropa. Hasil tinjauan memberikan posisi riset terkini serta usulan riset ke depan mengenai penerapan model copula untuk analisis kebakaran butan dan laban di Indonesia. Kata kunci: copula; kebakaran butan; studi literatur sistematik.
\end{abstract}

\section{INTRODUCTION}

Wildfires in Indonesia have become a crucial issue and have attracted the attention of various people, especially in Sumatra and Kalimantan [1]. Based on the burned area recapitulation per province in Indonesia, Sumatra and Kalimantan are the largest burned areas with percentages of 36 and 34\% of the total burned area [2]. It is related to the peatland area over South Sumatra and Central Kalimantan. These two provinces have peatland areas of 14,600 and $30,400 \mathrm{~km}^{2}$, respectively, with 19,400 and 20,300 hotspot occurrences in 2015 [3].

Submitted August 13 $3^{\text {th }}, 2021$, Revised September $5^{\text {th }}, 2021$, Accepted for publication September $12^{\text {th }}, 2021$. This is an open access article under CC-BY-SA license (https://creativecommons.org/licence/by-sa/4.0/) 
A wildfire prediction model is needed to reduce forest area losses. So far, the prediction model issued by the Meteorology, Climatology, and Geophysics Agency of Indonesia (BMKG) is still experimental and unofficial [4]. Therefore, research in predicting the wildfires risk in Indonesia is very potential and needs to be developed.

A fire risk model can be defined as a conditional probability of fire size (such as the number of hotspots) when given specific climatic conditions [5]. To construct this conditional probability, a joint distribution function between fire size and climatic conditions is needed. The copula function provides an easy way to construct the joint probability distribution between random variables. The copula function is a function that links the univariate distribution functions to the multivariate joint distribution function [6].

Initially, the copula function was applied in the financial fields. Many literature studies on the copula model in finance, such as a review of pair-copula construction in financial applications [7] and a review of the copula on economic time series [8]. The copula model began to develop in environmental sciences, especially in hydrology and water resources [9]. However, wildfire analysis that uses the copula model is still very few, especially in Indonesia.

Therefore, this review article aims to study the application of the copula model in wildfires analysis. We use the Systematic Literature Review (SLR) for descriptive analysis and article synthesis. The results are expected to provide information on the current research position and future research opportunities on applying the copula model in wildfires analysis, especially in Indonesia.

\section{METHOD}

We use the Systematic Literature Review (SLR) for descriptive analysis [10]. SLR is used to provide a comprehensive overview of the research topic [11]. In detail, the SLR process can be seen in Figure 1.

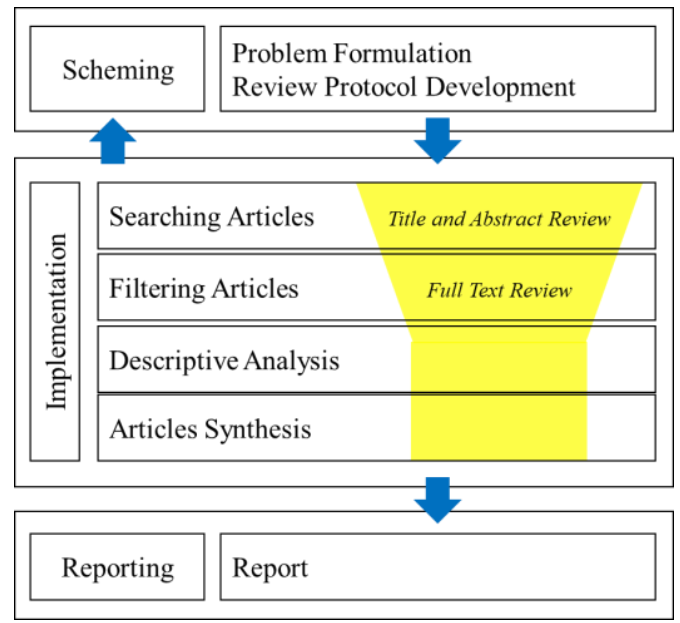

Figure 1. The systematic literature review process.

At the scheming stage, the inclusion criteria that will be used in the searching and filtering articles process are defined, such as

a. We search reputable articles and indexed by Scopus;

b. The article keyword is copula and forest fire (or wildfire); and 
c. The filtering process is used to eliminate articles that do not match the theme, i.e., applying the copula model in wildfires analysis.

The descriptive analysis provides an overview of the current research position related to the copula model in wildfires analysis at the implementation stage. The collected articles are classified based on the publication's year, publication's source, variables (climate indices) used, and study results. Furthermore, articles were synthesized to discuss the contribution of articles in wildfires analysis. The development of research opportunities related to applying the copula model in wildfires analysis in Indonesia is constructed based on the results of literature studies and also based on climatic conditions that affect wildfires in Indonesia.

\section{RESULTS AND DISCUSSION}

In this section, we discuss the concept of the copula model that can be applied in wildfires analysis, the result of the literature study, and research opportunities for the development of the copula model in wildfires analysis in Indonesia. First, we discuss the literature study about the concept of the copula as follows.

\subsection{The Concept of the Copula}

Before discussing the articles and reviewing the opportunities in the application of the copula model to wildfires analysis in Indonesia, we will first discuss the copula concept along with other techniques that are often used, such as dependence analysis, coincidence probability, conditional probability, and joint return period.

\subsubsection{Dependence Analysis}

The dependency coefficient shows how two (or more) variables are grouped [9]. The dependency coefficient in multivariate cases includes linear correlation, rank (or monotonous) correlation, positive quadrant dependency, tail dependency, and others. Copula model analysis usually uses the Kendall- $\tau$ correlation coefficient and tail dependency to measure dependencies, especially in the extreme (tail) regions.

The Kendall- $\tau$ rank correlation provides a measure of the degree of association between variables. In contrast to linear correlation, rank correlation can capture non-linear relationships between variables. Values for each pair of variables will also be used to determine a statistically significant correlation between the two, if $H_{0}: \tau=0$ can be rejected [12]. Rank correlation has been commonly used to measure non-linear dependencies between variables and overcome the weakness of linear correlation coefficients to some extent. However, this correlation may fail to measure dependencies in the extreme or tail [9].

The Kendall- $\tau$ rank correlation only measures the degree of the relationship between random variables in general. Still, it does not measure the dependencies in a particular part of the distribution (such as the extreme or tail regions), which may be more attractive in practical applications of extreme modeling. Tail dependency measures the probability of two random variables in the extreme region and is suitable when extreme dependencies are the main focus. In the bivariate copula, the dependencies on the upper right (upper tail) and lower left (lower tail) regions were the most interesting. The upper (bottom) tail dependency - denoted by $\lambda_{U}\left(\lambda_{L}\right)$ - of the random variables $X$ and $Y$ with marginal distributions $F(x)$ and $G(y)$ is given by 


$$
\begin{aligned}
& \lambda_{U}=\lim _{t \rightarrow 1} P\left(Y>G^{-1}(t) \mid X>F^{-1}(t)\right) \\
& \lambda_{L}=\lim _{t \rightarrow 0} P\left(Y \leq G^{-1}(t) \mid X \leq F^{-1}(t)\right)
\end{aligned}
$$

A random variables pair has an upper (bottom) tail dependency if $0<\lambda_{U} \leq 1\left(0<\lambda_{L} \leq 1\right)$ and has no upper (bottom) tail dependency if $\lambda_{U}=0\left(\lambda_{L}=0\right)$ [9].

\subsubsection{Copula Function}

Let $X$ is a collection of $m$-dimensional random variables, i.e., $X_{1}, \ldots, X_{m}$ in real domain area, and has a marginal cumulative distribution function (CDF) i.e., $F_{1}, \ldots, F_{m}$, respectively. Copula function $\left(C_{X}\right)$ is defined as a function that connects the multivariate joint distribution $F_{X}\left(x_{1}, \ldots, x_{m}\right)$ with its univariate marginal distributions $F_{i}\left(x_{i}\right)$ for $i=1,2, \ldots, m[13]$ given by

$$
F_{X}\left(x_{1}, \ldots, x_{m}\right)=C_{X}\left[F_{1}\left(x_{1}\right), \ldots, F_{m}\left(x_{m}\right)\right]=C_{X}\left[u_{1}, \ldots, u_{m}\right]
$$

where $C_{X}:[0,1]^{m} \rightarrow[0,1]$ is the joint distribution function of the random variable transformed by $u_{i}=F_{i}\left(x_{i}\right)$ for $i=1,2, \ldots, m$. Because of the transformation, $u_{i}$ always has a uniform $(0,1)$ marginal distribution function [14]. The copula function is unique if the marginal distribution is continuous [15]. However, this approach can easily be extended to discrete and continuous mixed random variables [6]. Therefore, $C_{X}$ is unique because the type of fire size is usually discrete and climate conditions are usually continuous and can be written as

$$
C_{X}\left(u_{1}, \ldots, u_{m}\right)=\int_{0}^{u_{m}} \cdots \int_{0}^{u_{1}} c_{X}\left(u_{1}^{\prime}, \ldots, u_{m}^{\prime}\right) d u_{1}^{\prime} \ldots d u_{m}^{\prime}
$$

where $u_{i}=F_{i}\left(x_{i}\right)$ for $i=1,2, \ldots m$. The function $C_{X}$ is called the copula function, and $c_{X}$ is the probability density function. An important consequence [13] is that each joint probability density function can be written as the product of the marginal density functions $f_{1}, \ldots f_{m}$ and its copula probability density function $c_{X}$, given by

$$
f_{X}\left(x_{1}, \ldots, x_{m}\right)=f_{1}\left(x_{1}\right) \cdots f_{m}\left(x_{m}\right) \cdot c_{X}\left(u_{1}, \ldots, u_{m}\right)
$$

Differences in the copula distribution function will provide different descriptions of the dependency structure [16]. Empirically, the copula distribution function can be approximated using the following equation [15].

$$
C_{n}\left(\frac{i}{n}, \frac{j}{n}\right)=\frac{\#\left(x \leq x_{(i)}, y \leq y_{(j)}\right)}{n}
$$

where $x_{(i)}$ and $y_{(j)}(1 \leq i, j \leq n)$ are statistical sequences of the data. Alternatively, the empirical copula function can also be approximated by the Gringorten formula [17].

Parametric copulas are an important alternative. There are many families of parametric copulas, including the meta-elliptic copula (Gaussian and Student's t), Archimedean copula (Clayton, Gumbel, Frank, and Joe), extreme value copula (Galambos copula, extremal-t copula, and Husler-Reiss copula ), and other families (e.g. the Plackett family) [18]-[23]. An essential step in determining a parametric copula is the selection of the most suitable copula. Empirical copulas are usually used to assist in the 
selection of copula families. Moreover, statistical tests, such as Akaike's Infirmation Criterion, Cramervon Mises, and Kolmogorov-Smirnov statistics, can be used to select the appropriate copula function [9].

\subsubsection{Coincidence and Conditional Probability}

Coincidence probability or exceedance probability is used to analyze the probability of two or more events occurring simultaneously. In hydrological analysis, climatic conditions are divided into three conditions (dry, normal, and wet) [24], [25]. The probability of joint occurrences of dry-dry, normal-normal, wet-wet, dry-wet, and so on is calculated from the three climatic conditions. Suppose that the dry condition of the random variable $X$ is given by $X \leq X_{d}$ and the wet condition $X>X_{w}$, then some coincidence probability calculations are given by

$$
\begin{aligned}
& P_{w w}=P\left(X>X_{w}, Y>Y_{w}\right)=1-u_{w}-v_{w}+C_{X}\left(u_{w}, v_{w}\right) \\
& P_{d d}=P\left(X \leq X_{d}, Y \leq Y_{d}\right)=C_{X}\left(u_{d}, v_{d}\right) \\
& P_{w d}=P\left(X>X_{w}, Y \leq Y_{d}\right)=v_{w}-C_{X}\left(u_{w}, v_{d}\right)
\end{aligned}
$$

where $u$ and $v$ are the marginal distributions of $X$ and $Y$, while the indices $w, n$, and $d$ represent wet, normal, and dry conditions, respectively. For example, the index $d d$ represents the dry-dry condition, and $P_{d d}$ is the probability of this condition [17].

Meanwhile, conditional probability is also often used in analysis using the copula model. One such study is Madadgar et al. [5] which uses conditional probability to define a fire risk model. That research is interested in the probability that the fire size $Y$ exceeds a specific threshold $y$, under climatic conditions $X$ is equal to $x$, namely $F_{Y \mid X}(Y>y \mid X=x)$, and the conditional probability is $f_{Y \mid X}(y \mid x)$ defined by

$$
f_{Y \mid X}(y \mid x)=\frac{f_{X Y}(x, y)}{f_{X}(x)}=\frac{c\left[F_{X}(x), F_{Y}(y)\right] \cdot F_{X}(x) \cdot F_{Y}(y)}{F_{X}(x)}=c\left[F_{X}(x), F_{Y}(y)\right] \cdot F_{Y}(y)
$$

The conditional probability $F_{Y \mid X}(Y>y \mid X=x)$ is the area of $f_{Y \mid X}(y \mid x)$ with the origin $Y>y$ [5].

\subsubsection{Joint Return Period}

The expected value of the drought inter-arrival time (DIT; the time between two consecutive drought events) is one of the most common drought characteristics to be analyzed in hydrological and water resource system applications [26]. Theoretically, the return period $(T)$ of drought with univariate drought characteristics is given by

$$
T_{U>u}=\frac{E(D I T)}{P(U>u)}
$$

where $E(D I T)$ is the expected value of DIT and $T_{U>u}$ is the return period of drought, which is determined by $u$. E(DIT) was calculated as the ratio of the total duration to the total number of droughts. It is also possible to extend the return period to the bivariate case by characterizing events with a coincidence or conditional probability [27], [28], i.e 


$$
\begin{aligned}
& T_{(U>u \cap V>v)}=\frac{E(D I T)}{P(U>u \cap V>v)} \\
& T_{(U>u \cup V>v)}=\frac{E(D I T)}{P(U>u \bigcup V>v)} \\
& T_{(U>u \mid V>v)}=\frac{E(D I T)}{P(U>u \mid V>v)}
\end{aligned}
$$

\subsection{The Result of the Literature Study}

From the article search results, we found seven reputable articles indexed by Scopus that match specific keywords until June 2021. After the article filtering process, one article did not match the theme, so the article was eliminated and six articles remained. The literature study results are written in two parts, i.e., the distribution of articles containing descriptive analysis and the description of articles containing a synthesis of articles.

\subsubsection{The Distribution of Articles}

Table 1 shows the distribution of articles by year, journal name, and data used. Meanwhile, Figure

\begin{tabular}{|c|c|c|c|c|c|c|c|c|}
\hline \multirow{2}{*}{ Author(s) } & \multirow{2}{*}{ Year } & \multirow{2}{*}{ Journal Name } & \multicolumn{6}{|c|}{ Data* } \\
\hline & & & A & $\mathrm{B}$ & $\mathrm{C}$ & $\mathrm{D}$ & $\mathrm{E}$ & $\mathrm{F}$ \\
\hline Manning et al. [29] & 2018 & J. Hydrometeorol. (Q1) & $\bullet$ & $\cdot$ & $\cdot$ & & & \\
\hline Singh et al. [30] & 2020 & Theor. Appl. Climatol (Q2) & & & • & • & & \\
\hline $\mathrm{Xi}$ et al. [31] & 2020 & Environmetrics (Q2) & & & • & & • & - \\
\hline Tilloy et al. [32] & 2020 & Nat. Hazards Earth Syst. Sci. (Q1) & & & & • & • & \\
\hline Zscheischler \& Fischer [33] & 2020 & Weather. Clim. Extremes (Q1) & & & $\bullet$ & • & & \\
\hline Madadgar et al. [5] & 2020 & $\begin{array}{l}\text { Stoch Environ Res Risk Assess. } \\
\text { (Q1) }\end{array}$ & & & - & $\bullet$ & • & \\
\hline
\end{tabular}
2 shows the number of articles and citations each year.

Table 1. The distribution of the six articles by year, journal name, and data used.

The application of the copula model in wildfires analysis is still very few and has only been developed in the last three years. The first reputable article was published in 2018, and there were only six articles recorded until August 2021. The six articles were published under different journal names, i.e., four articles (67\%) in Q1 ranked journals, and the rest (33\%) in Q2 ranked journals. Based on the data used, it can be used fire indicators and also local climate indicators. Table 1 shows that the copula model can be applied to fire analysis directly (using fire data) or indirectly (not using fire data) with a percentage of $50 \%$ each. In the indirect wildfires analysis, the indicators used are closely related to wildfires, such as soil moisture, potential evapotranspiration, rainfall, and temperature. Meanwhile, in the direct wildfires analysis, the indicators used are the fire size and duration.

Based on Figure 2, research development using the copula model for wildfires analysis has increased from 1 article in 2018 to 5 articles in 2020. Although the number of studies is very few, the number of article citations every year always increases from 5 citations in 2019 to 34 citations in January - August 2021, showing the article's importance and contribution to the development of wildfires analysis. 


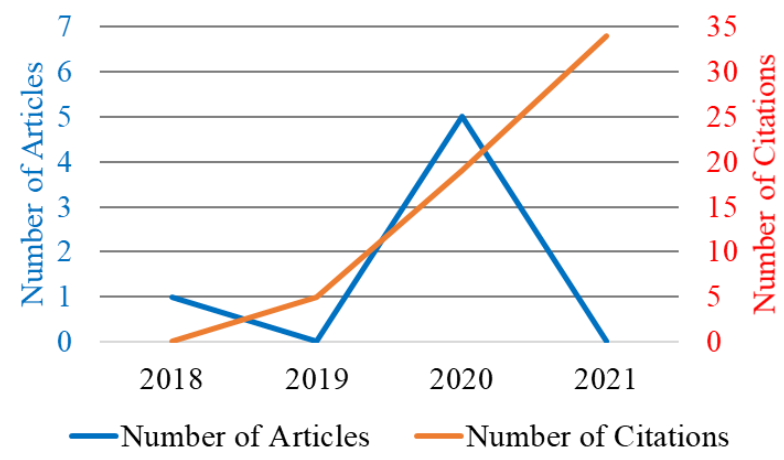

Figure 2. The number of articles and citations each year.

\subsubsection{The Description of Articles}

Table 2. Synthesis of each article.

\begin{tabular}{lll}
\hline Authors & Method(s) & Location Research \\
\hline Manning et al. [29] & Pair Copula Constructions (PCCs) & Europe \\
Singh et al. [30] & 39 different bivariate copulas & Canada \\
Xi et al. [31] & Four copulas and three joint models & Canada \\
Tilloy et al. [32] & Copulas, extreme conditional model, and joint tail & England \& Portugal \\
Zscheischler \& Fischer & Bivariate return period based on copula & Germany \\
[33] & & \\
Madadgar et al. [5] & Conditional probability based on copula & United State \\
\hline
\end{tabular}

Based on Table 2, the copula model applied in wildfires analysis was initiated by Manning et al. in 2018 [29]. However, this research does not discuss wildfires directly but discusses soil moisture drought, which fuels fires. Using the Pair Copula Constructions (PCCs), the study models soil moisture drought as a combined event between precipitation and potential evapotranspiration on various timescales in Europe. The results showed that soil moisture drought was more influenced by precipitation, while potential evapotranspiration was only used to explain the severity of drought conditions in wet climates. Increasing drought severity will increase energy availability which can contribute to environmental hazards such as heatwaves and wildfires. Another indirect fire analysis was also carried out by Singh et al. [30] and Zscheischler \& Fischer [33], which examined the relationship between precipitation and temperature, in particular examining dry-hot climate conditions that can increase fire risk. Singh et al. [30] use copulas to describe the joint behavior of temperature and precipitation in 15 ecozones over Canada on several time scales. Analysis on a seasonal and monthly scale shows an increase in warm-wet conditions in winter and hot-dry conditions in summer.

Meanwhile, Zscheischler \& Fischer [33] examined extremely hot temperatures in 2018, particularly Germany, accompanied by deficient precipitation. With data dating back to 1881, Germany's extremely dry and hot conditions in March-November 2018 were unprecedented. This study analyzes the rarity of such events and estimates the return period to be very high but very uncertain depending on the method used.

The first article to analyze wildfires directly using the copula model is Xi et al. [31]. This study modeled fire duration and size in British Columbia, Canada, using the copula model as a survival 
outcome. Small changes in the average deviation from the threshold of precipitation will affect fire size substantially. In another study, Tilloy et al. examined the interrelationship between temperature and burned area in Porto, Portugal [32]. This study explores multi-hazard events and identifies the most efficient model for a specific synthetic data (hazard) set. This study has two cases i.e., (1) exploring the interrelationship between precipitation and wind gusts at Heathrow airport in London, England, and (2) exploring the interrelationship between temperature and wildfires in Portugal. In analyzing temperature and wildfires, the Gumbel, Galambos, joint tail KDE (Kernel Density Estimation) copula models are the most relevant models. Meanwhile, Madadgar et al. [5] proposed a multivariate probabilistic approach to measure fire risk with different climatic conditions in California. The probability of annual fire size exceeding its long-term average, increasing by 30\% when the summer temperature anomaly increases by $1^{\circ} \mathrm{C}$ (from $-0.5^{\circ} \mathrm{C}$ to $+0.5^{\circ} \mathrm{C}$ ) and doubles when rainfall decreases from the 75 th (wet) to the 25 th (dry) percentile.

The bivariate copula model dominates experts who use the copula model in wildfires analysis, and no research has been found that applies the multivariate copula model in its analysis. This type of research is very likely to be applied in Indonesia, considering that wildfires often occur. Thus, the results can help stakeholders anticipate the occurrence of massive wildfires, such as in 2015 and 2019.

\subsection{Development Opportunities of the Copula Model in Wildfires in Indonesia}

It has been previously researched that fires in Indonesia are strongly influenced by local climatic conditions (such as precipitation and dry spells) and regional climatic conditions such as the Indian Ocean Dipole (IOD) and El Nino-Southern Oscillation (ENSO) [34], [35]. Based on the systematic literature review description, several research opportunities related to the copula model in wildfires analysis in Indonesia can be proposed with a research roadmap, as shown in Figure 3.

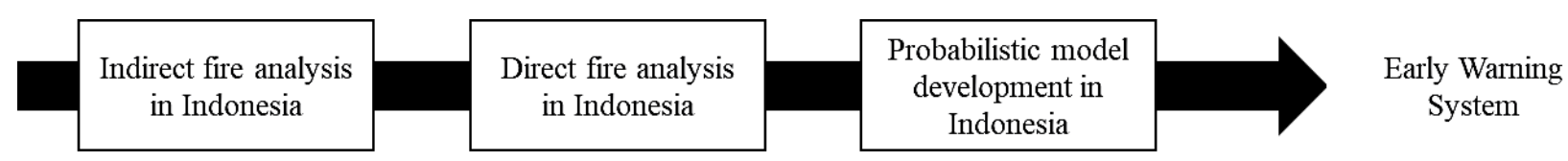

Figure 3. Research development opportunities related to copula model in fire analysis in Indonesia.

By modifying the research [29], [30], [33], indirect fire analysis in Indonesia using copulas can be researched on local and regional climate conditions that affect wildfires in Indonesia, such as temperature, rainfall intensity, dry spells, ENSO, and IOD conditions. By using coincidence probability, we can analyze the probability of dry and hot climatic conditions that could exacerbate wildfires in Indonesia. Also, the return period of dry and hot climatic conditions can be analyzed using the joint return period.

The following research proposal is a direct fire analysis using data on wildfires in Indonesia. By modifying the study [5], [31], [32], copula model analysis can be applied to climate and wildfires data in Indonesia to identify the joint probability and relationships between each data. Also, a fire risk model in Indonesia can be developed using conditional probability [5]. Therefore, the result can be used as an early warning system for wildfires in Indonesia. 


\section{CONCLUSION}

The copula model can be implemented in various research fields, including wildfires analysis. The literature study results using the Systematic Literature Review (SLR) method provide the latest research position regarding the application of the copula model in wildfires analysis. Overall, the application of the copula model in wildfires analysis is still very few. However, the increasing number of article citations each year shows the importance of this research and has contributed to the development of wildfires analysis. A total of $67 \%$ of articles were published in Q1 ranked journals, and 33\% in Q2 ranked journals. In that article, 50\% of the studies applied the copula model to direct fire analysis (using fire data) in Canada, Portugal, and America. Meanwhile, the other $50 \%$ applied the copula model to indirect fire analysis (not using fire data), in Canada and the European region.

Research opportunities for applying the copula model in wildfires analysis are still wide open, especially in Indonesia. Wildfires analysis can directly/indirectly increase knowledge about the relationship between climate conditions and wildfires in Indonesia. Moreover, a fire risk model using the copula model can be developed by considering the climatic conditions in Indonesia. Therefore, the result of the fire risk model can be used as an early warning system for wildfires in Indonesia.

Funding: This research received no external funding.

Conflicts of Interest: The authors declare no conflict of interest.

\section{REFERENCES}

[1] E. Aflahah, R. Hidayati, and R. Hidayat, "Pendugaan hotspot sebagai indikator kebakaran hutan di Kalimantan berdasarkan faktor iklim," J. Pengelolaan Sumberd. Alam dan Lingkung., vol. 9, no. 2, pp. 405-418, 2019, doi: 10.29244/jps1.9.2.405-418.

[2] MENLHK, "Rekapitulasi Luas Kebakaran Hutan dan Lahan (Ha) Per Provinsi Di Indonesia Tahun 2016-2021," 2021. http://sipongi.menlhk.go.id/hotspot/luas_kebakaran (accessed Aug. 11, 2021).

[3] J. Miettinen, C. Shi, and S. C. Liew, "Fire Distribution in Peninsular Malaysia, Sumatra and Borneo in 2015 with Special Emphasis on Peatland Fires," Environ. Manage., vol. 60, no. 4, pp. 747-757, 2017, doi: 10.1007/s00267-017-0911-7.

[4] BMKG, "Climate Index for Suitability of Hotspots Occurence in ASEAN Regions," 2021. http://puslitbang.bmkg.go.id/karhutla/ (accessed Aug. 11, 2021).

[5] S. Madadgar, M. Sadegh, F. Chiang, E. Ragno, and A. AghaKouchak, "Quantifying increased fire risk in California in response to different levels of warming and drying," Stoch. Environ. Res. Risk Assess., vol. 34, no. 12, pp. 2023-2031, 2020, doi: 10.1007/s00477-020-01885-y.

[6] C. Schölzel and P. Friederichs, "Multivariate non-normally distributed random variables in climate research - Introduction to the copula approach," Nonlinear Process. Geophys., vol. 15, no. 5, pp. 761-772, 2008, doi: 10.5194/npg-15-761-2008.

[7] K. Aas, "Pair-copula constructions for financial applications: A review," Econometrics, vol. 4, no. 4, 2016, doi: 10.3390/econometrics4040043.

[8] A. J. Patton, “A review of copula models for economic time series," J. Multivar. Anal., vol. 110, pp. 4-18, 2012, doi: 10.1016/j.jmva.2012.02.021.

[9] Z. Hao and V. P. Singh, "Review of dependence modeling in hydrology and water resources," Prog. Phys. Geogr., vol. 40, no. 4, pp. 549-578, 2016, doi: 10.1177/0309133316632460.

[10] F. D. Wihartiko, S. Nurdiati, A. Buono, and E. Santosa, "Blockchain dan Kecerdasan Buatan 
dalam Pertanian : Studi Literatur," J. Teknol. Inf. dan Ilmu Komput., vol. 8, no. 1, p. 177, 2021, doi: 10.25126/jtiik.0814059.

[11] Y. Xiao and M. Watson, "Guidance on Conducting a Systematic Literature Review," J. Plan. Educ. Res., vol. 39, no. 1, pp. 93-112, 2019, doi: 10.1177/0739456X17723971.

[12] R. Jane, L. Cadavid, J. Obeysekera, and T. Wahl, "Multivariate statistical modelling of the drivers of compound flood events in South Florida," Nat. Hazards Earth Syst. Sci., pp. 1-30, 2020, doi: 10.5194/nhess-2020-82.

[13] M. Sklar, "Fonctions de Répartition àn Dimensions et Leurs Marges," Publ. L'Institut Stat. L’Université Paris, vol. 8, pp. 229-231, 1959.

[14] P. Laux, S. Vogl, W. Qiu, H. R. Knoche, and H. Kunstmann, "Copula-based statistical refinement of precipitation in RCM simulations over complex terrain," Hydrol. Earth Syst. Sci., vol. 15, no. 7, pp. 2401-2419, 2011, doi: 10.5194/hess-15-2401-2011.

[15] R. B. Nelsen, An Introduction to Copulas. New York: Springer, 2006.

[16] Z. Li, Q. Shao, Q. Tian, and L. Zhang, "Copula-based drought severity-area-frequency curve and its uncertainty, a case study of Heihe River basin, China," Hydrol. Res., vol. 51, no. 5, pp. 867-881, 2020, doi: 10.2166/nh.2020.173.

[17] X. Wei, H. Zhang, V. P. Singh, C. Dang, S. Shao, and Y. Wu, "Coincidence probability of streamflow in water resources area, water receiving area and impacted area: Implications for water supply risk and potential impact of water transfer," Hydrol. Res., vol. 51, no. 5, pp. 1120_ 1135, 2020, doi: 10.2166/nh.2020.106.

[18] F. A. A. Aldhufairi, R. G. M. Samanthi, and J. H. Sepanski, "New families of bivariate copulas via unit Lomax distortion," Risks, vol. 8, no. 4, p. 106, 2020, doi: 10.3390/risks8040106.

[19] C. Genest, A. C. Favre, J. Béliveau, and C. Jacques, "Metaelliptical copulas and their use in frequency analysis of multivariate hydrological data," Water Resour. Res., vol. 43, no. 9, 2007, doi: 10.1029/2006WR005275.

[20] Z. Hao and V. P. Singh, "Integrating entropy and copula theories for hydrologic modeling and analysis," Entropy, vol. 17, no. 4, pp. 2253-2280, 2015, doi: 10.3390/e17042253.

[21] O. Orcel, P. Sergent, and F. Ropert, "Trivariate copula to design coastal structures," Nat. Hazards Earth Syst. Sci., vol. 21, no. 1, pp. 239-260, 2020, doi: 10.5194/nhess-2020-80.

[22] D. Sirikanchanarak, J. Liu, S. Sriboonchitta, and J. Xie, "Analysis of transmission and comovement of rice export prices between Thailand and Vietnam," in Studies in Computational Intelligence, vol. 622, Cham: Springer, 2016, pp. 333-346.

[23] L. Zhang and V. P. Singh, "Symmetric Archimedean Copulas," in Copulas and their Applications in Water Resources Engineering, Cambridge University Press, 2019, pp. 123-171.

[24] B. Yan and L. Chen, "Coincidence probability of precipitation for the middle route of Southto-North water transfer project in China," J. Hydrol., vol. 499, pp. 19-26, 2013, doi: 10.1016/j.jhydrol.2013.06.040.

[25] H. Du, Y. Wang, K. Liu, and L. Cheng, "Exceedance probability of precipitation for the Shuhe to Futuan Water Transfer Project in China," Environ. Earth Sci., vol. 78, no. 7, pp. 1-12, 2019, doi: 10.1007/s12665-019-8207-2.

[26] M. H. Afshar, A. U. Sorman, and M. T. Yilmaz, "Conditional copula-based spatial-temporal drought characteristics analysis-A case study over Turkey," Water (Switzerland), vol. 8, no. 10, 2016, doi: 10.3390/w8100426.

[27] M. H. Afshar, A. Ü. Şorman, F. Tosunoğlu, B. Bulut, M. T. Yilmaz, and A. Danandeh Mehr, "Climate change impact assessment on mild and extreme drought events using copulas over Ankara, Turkey," Theor. Appl. Climatol., vol. 141, no. 3-4, pp. 1045-1055, 2020, doi: 10.1007/s00704-020-03257-6. 
[28] F. Tosunoğlu, G. Salvadori, and M. Yilmaz, "Multivariate assessment of low-flow hazards via copulas: The case study of the Çoruh basin (turkey)," Water (Switzerland), vol. 12, no. 10, 2020, doi: $10.3390 /$ w12102848.

[29] C. Manning, M. Widmann, E. Bevacqua, A. F. Van Loon, D. Maraun, and M. Vrac, "Soil moisture drought in Europe: A compound event of precipitation and potential evapotranspiration on multiple time scales," J. Hydrometeorol., vol. 19, no. 8, pp. 1255-1271, 2018, doi: 10.1175/JHM-D-18-0017.1.

[30] H. Singh, F. J. Pirani, and M. R. Najafi, "Characterizing the temperature and precipitation covariability over Canada," Theor. Appl. Climatol., vol. 139, no. 3-4, pp. 1543-1558, 2020, doi: 10.1007/s00704-019-03062-w.

[31] D. D. Z. Xi, C. B. Dean, and S. W. Taylor, "Modeling the duration and size of extended attack wildfires as dependent outcomes,” Environmetrics, vol. 31, no. 5, 2020, doi: 10.1002/env.2619.

[32] A. Tilloy, B. Malamud, H. Winter, and A. Joly-Laugel, "Evaluating the efficacy of bivariate extreme modelling approaches for multi-hazard scenarios," Nat. Hazards Earth Syst. Sci., pp. 139, 2020, doi: 10.5194/nhess-2020-28.

[33] J. Zscheischler and E. M. Fischer, "The record-breaking compound hot and dry 2018 growing season in Germany," Weather Clim. Extrem., vol. 29, 2020, doi: 10.1016/j.wace.2020.100270.

[34] S. Nurdiati, A. Sopaheluwakan, and P. Septiawan, "Spatial and Temporal Analysis of El Niño Impact on Land and Forest Fire in Kalimantan and Sumatra," Agromet, vol. 35, no. 1, pp. 1-10, 2021, doi: 10.29244/j.agromet.35.1.1-10.

[35] S. Nurdiati, F. Bukhari, M. T. Julianto, M. K. Najib, and N. Nazria, "Heterogeneous Correlation Map Between Estimated ENSO And IOD From ERA5 And Hotspot In Indonesia," Jambura Geosci. Rev., vol. 3, no. 2, pp. 65-72, 2021, doi: 10.34312/jgeosrev.v3i2.10443. 